\title{
Mamluks in Abbasid Society
}

\author{
Lutz Berger
}

\section{1 Introduction}

Slave soldiers existed in many societies, already in the ancient Mediterranean world, but also in the age of European imperialism. Nonetheless, it is fair to say that there were few places, if at all, where the enslavement of foreigners was as important for recruiting elite soldiers as in the premodern Islamic world. Nor did slave soldiers anywhere else become as influential politically. The bestknown premodern Muslim polity based primarily on an elite of slave soldiers was the Mamluk Sultanate in Egypt. However, the Mamluk army of Egypt was by no means the only nor the earliest slave army in the Muslim world. The aim of the present paper is to present the reader with a short survey of what we know about the origins of Muslim slave armies in the early Abbasid period and with some ideas on their impact on the societies in question. ${ }^{1}$

The history of these armies has been subject to some debate among scholars ever since the late 196os. Among the first studies were Ayalon's who saw the functioning of slave armies of the Abbasids very much through the eyes of an expert on the late medieval Mamluk institution in Egypt (by projecting later facts back into early Abbasid times $)^{2}$ The same holds true for Töllner's 1971 dissertation. ${ }^{3}$ In the mid-1970s, Shaban in his revisionist tour de force of early Islamic history doubted that something like slave soldiers existed at all in Abbasid times. In his view, when the sources spoke of slavery it was just a metaphor for the fidelity of high-ranking soldiers towards their master, the caliph. ${ }^{4}$ Pipes and Crone in the late 1970 did not follow Shaban's ideas. In their opinion, the armies of the 9th-century caliphs consisted primarily of foreign slaves, be it, as Pipes argues, because the Muslims were not willing to serve in the army anymore, be it, as Crone contends, that the rulers of the Islamic world

1 I have omitted the mentioning of authors of primary sources and have restricted myself on the citation of secondary literature in Western languages instead. An important research tool on all questions pertaining to medieval slavery in Europe and the Middle East is http://medslavery.uni-trier.de/ (accessed 17 August 2018).

2 Ayalon, "Military Reforms"; Ayalon, "Preliminary Remarks"; Amitai, "The Rise and Fall".

3 Töllner, Türkische Garden.

4 Shaban, Islamic History.

(C) LUTZ BERGER, 2020 | DOI:10.1163/9789004425613_015

This is an open access chapter distributed under the terms of the CC BY-NC 4.o Licenseutz Berger - 9789004425613 
wanted to be independent of their Muslim constituency. ${ }^{5}$ As it seems today, most of the arguments brought forward in these debates have their validity but at the same time need to be nuanced. This is possible not least because lately scholars did not focus only on what happened at the caliph's court in Baghdad or Samarra, or on Turkish and other Central Asian troops there. Some, like Bacharach and Lev, took a deeper interest in the Western provinces of the caliphate and the role of African soldiers. ${ }^{6}$ Paul, a specialist on Central Asia, insisted that whatever the role and nature of slave armies might have been, we should not underrate the continuing presence of free, indigenous soldiers in the armies of the caliphs. ${ }^{7}$ De la Vaissière provided us with invaluable insights in the Central Asian world whence so many of the elite soldiers of the Abbasids stemmed and helped us to a better understanding of the origins of the Mamluk phenomenon at the Abbasid court. ${ }^{8}$ Thanks to him, the problem that once puzzled Shaban of whether or not the Turkish soldiers of 9 th-century Iraq were slaves now seems finally solved. ${ }^{9}$

The migration of military elites into the Abbasid Empire has to be put into the setting of the political history of the time. ${ }^{10}$ The Abbasids took power in $75^{\circ}$ as leaders of the revolution that put an end to the Umayyad dynasty. Their supporters were a motley crew of elite groups, both Arabs and converts to Islam, from the Eastern half of the Empire, mostly from Khorasan. They expected the new dynasty to bring justice where they perceived injustice, but most of all they expected to participate in the spoils of victory. The core of the revolutionary troops, the so-called abnä al-dawla, "sons of the revolution", remained in Iraq as the mainstay of the new government. They received decent allowances from the tax income of the Empire, especially Iraq, which was at the time by far the richest of the provinces of the Abbasid realm. The Abbasids held fast to it as well as to the provinces in the East as far as Central Asia and to the West as far as Egypt. What lay further off in the West, by contrast, was not really worthwhile keeping, given the logistical possibilities of the period. Therefore, the

\footnotetext{
Pipes, Slave Soldiers; Crone, Slaves on Horses; Crone, "Early Islamic World". Bacharach, "African Military Slaves”; Lev, "David Ayalon".

Paul, The State and the Military.

8 De la Vaissière, Samarcande et Samarra.

9 See below, n. 11.

10 Cobb, "Empire in Syria"; El-Hibri, "Empire in Iraq"; Bonner, "Waning of Empire”; Sourdel, L'État impérial.
} 
Abbasids let al-Andalus and what is now Morocco go their own ways. Both provinces had up to that time been rather more costly to keep than to lose. Ifrīqiyā, i.e. Tunisia and its borderlands, was given to loyal supporters in return for a yearly tribute. The relative stability of the first century of Abbasid rule, the fact that there was no breaking away of further provinces, was due to the cultural and political unity of the imperial administrative and military elite. There was a good deal of elite circulation in the Abbasid Empire back and forth within the Empire, and for most keeping contact with the financially and culturally rich imperial centre in Iraq was more attractive than trying to break away. In Ifrīqiyā, as we have seen, as well as in the East, especially in Central Asia, a large degree of local autonomy made belonging to the Empire a burden that was not too heavy to bear.

Things started to change with a civil war that was caused by the disunity of the caliph Hārūn al-Rāshīd's sons after the former's death in 809. One of the brothers, al-Amin, had been created caliph in his father's place, the other, al-Ma'mūn, was supposed to be his successor, and in the meantime had been appointed governor of Khorasan. This arrangement, all the precautions their father had taken notwithstanding, proved to be a fragile one. Things came to a head when al-Ma'mūn, supported by al-Ṭāhir, the commander of his troops and a leading representative of the Khorasanian Arabs, marched on Baghdad. The majority of the $a b n \bar{a}$ s supported the rightful caliph, but were defeated by al-Ma'mūn's troops. As in $75^{\circ}$ Easterners now took over power in the centre of the caliphate. A large part of al-Tāhirs Khorasanian soldiers stayed in Baghdad after the successful takeover, while he himself became governor of the East under the new dispensation. Al-Ma'mūn and, later on, his brother and ultimate successor al-Mu'tașim had to see how they could counterbalance the power of their over-mighty subject at the very centre of their Empire with troops loyal to themselves. Among others, they brought in Central Asian troops for the purpose. The nature of these has long been subject to debate and it is only thanks to the painstaking and meticulous work of de la Vaissière that we understand the changes in the recruitment of military personnel more clearly. ${ }^{11}$

According to him, the social structures of Transoxania had remained surprisingly stable after the Muslim conquest. Under the overlordship of the caliph and his representative, small principalities and their landed warrior aristocracy continued to dominate the region. Within these principalities, princes gathered around themselves bands of loyal retainers. Such bands of warrior nobles were recruited into the Abbasid army especially from the times

11 De la Vaissière, Samarcande et Samarra. 
of al-Ma'mūn onwards. Some of these bands of warriors entered into Abbasid military service on their own accord, others had been transferred to Iraq as captives. Confronted with Taahirid regiments of this type that had helped al-Ma'mūn to win the throne, al-Mu'tașim chose to bring in troops of this origin. All of them were free or at least freed once in the service of the caliph. Just like the elite retainers of Central Asian princes, they were seen and probably saw themselves as the personal servants of the caliph. The idea of servanthood was more an expression of special loyalty than of legal status, though. To avoid conflict with both the population of Baghdad and the regiments of the Tâhirids, the caliph settled his new militia of about 8,00o men in a palace city of his own: Samarra. Nevertheless, it was not only Turks who were quartered there. Among others, Arabs from Egypt, the so-called Maghāriba, also found their place in the new capital and became allies of the Turks. ${ }^{12} \mathrm{~A}$ part at least of these Maghäriba had been enslaved as consequence of rebellions in Egypt, but others seem to have been free. ${ }^{13}$ In all, as it seems, around 20,000 troops or even a little more were stationed in the new capital. ${ }^{14}$ The troops of the Tăhirids stayed behind in Baghdad. To keep his new soldiers isolated, and maybe also to retain supposed racial traits such as good horsemanship, al-Mu'tașim brought in Turkish slave women for them with whom they had children who then were also integrated into the army. Relatively little is known about the training and career of slave soldiers. Those who had been brought into the Islamic world as prisoners of war needed little military training. At any rate, we do not have any concrete information about how such training took place in Samarra. Only at the end of the gth century do we hear of reviews of Turkish troops by the caliph who then would assign each of these horsemen to a certain rank and pay according to his respective performance. ${ }^{15}$

The hope that these newly recruited soldiers would give the caliphs a secure base on which their authority could rest durably soon turned out to be an illusion. The Central Asian army ate up a great part of the Empire's revenues and was not willing to give up that privileged position. Overall, the payment of the army was the most important item on the caliphs' budget and difficulties in providing the money needed were one of the root causes of political instability from the mid-9th century right through to the Būyid takeover in 945. In the end, the new Central Asian armies were in no way cheaper than the ancient

\footnotetext{
12 Talbi, "Maghāriba"; Kennedy, Armies of the Caliphs, pp. 119-120.

13 De la Vaissière, Samarcande et Samarra.

14 All these figures are very approximative. See Kennedy, Armies of the Caliphs, pp. 126-127 and in particular de la Vaissière, Samarcande et Samarra, pp. 238-239 for a discussion of numbers.

15 Kennedy, Armies of the Caliphs, pp. 157-158.
} 
Muslim militia, the djund, or other types of mercenaries. As it was not always easy for the government to provide ready cash for the Turkish troops, their demands led to the development of the oriental version of a fief, the $i q t \bar{a}^{c}$. Thereby the civil administration gave up the right to collect the taxes of a defined district, the $i q t \bar{a} \bar{c}$, for the benefit of an officer of the army. Although in theory this did not mean that these officers became owners of the land, there was a tendency for officers being given these iqtāis to keep them throughout their lives and even to leave them to their heirs. The system started in the region around Samarra but soon was extended to other parts of Iraq and of what is now Iran. ${ }^{16}$ Obviously, not all soldiers were paid by being granted such a fief. Those that were not depended on money handed out to them by their commanders or on stipends from the central treasury. The $i q t \bar{a}^{c}$ and other forms of conditional ownership of land or, mostly, of the land's tax income remained a central feature of the social system of the Muslim world through to the 19th century.

By the midst of the gth century, al-Mu'tașim's Turkish militia had become so powerful that the caliph al-Mutawakkil, the son of al-Mu'tașim, started to think of getting rid of it. When he attempted to confiscate the fiefs of one of his Turkish commanders, he was killed by the latter's soldiers in collusion with his heir apparent, who seems to have had fallen from grace. ${ }^{17}$ The murder of the caliph opened a period of anarchy in Samarra and Baghdad when different factions within the military vied for influence and control, setting up and toppling caliphs as they went. Apart from the Central Asian Turks who loom so large in our sources, the old troops of the Tāhirids in Baghdad and the so-called maghäriba already mentioned joined the fray. Furthermore, there were African infantrymen, the shäkiriyya (free guard troops of Eastern Iranian or Central Asian origin) and finally what was left over of the ancient djund and the $a b n \bar{a}$. All these groups now fought over power and influence in a never-ending merry-go-round of caliphs being set up and toppled. The crisis was compounded by the zandj, East African slaves who had to work in the salt swamps in the South of Iraq. They started a rebellion in protest against their dire living conditions. This rebellion laid waste much of the agricultural core of the Empire. ${ }^{18}$

This period of chaos ended when under the caliph al-Mu'tamid (ruled 870892) the caliph's brother and regent al-Muwaffaq created a new elite corps of Central Asian slave soldiers and regained control over the situation. This time these soldiers were real slaves. Unlike before, now new recruits were regularly

16 Gordon, "Turkish Military Elite"; Cahen, "Lévolution de l'iqtâ"; Lambton, "Eqtā"."

17 Kennedy, Armies of the Caliphs, pp. 137-138.

18 Apart from the literature given in note 10 above, see Kennedy, "Decline and Fall". 
bought and trained so as to prevent the formation of entrenched vested interests. ${ }^{19} \mathrm{Al}$-Muwaffaq succeeded to bind this new troop to his person and thereby had the instrument with which he could both subdue the warring factions of the army and the rebellious zandj.

Eventually though, the infighting of military and bureaucratic groups over the dwindling resources of the imperial centre resumed. This was finally yet importantly the result of the crisis of Iraqi agriculture. Much of the complicated system of desalination and irrigation had been destroyed by years of warfare. With Iraq impoverished and the provinces breaking away and not transferring great sums of money anymore to the centre, there was not enough money left in the treasury to satisfy everybody. The caliph al-Muqtadir (908932), unlike the Abbasids of the late 9th century, did never lead his army in person and was not able to create a bond with his slave soldiers. In the end, the Turkish military had the upper hand, and after the murder of al-Muqtadir the leader of the slave army was appointed commander in chief and the new caliph virtually ceded most of his executive power to him. This military dictatorship was not to last long. ${ }^{20}$ In the year 945, bands of mercenaries from Daylam in what is now northern Iran marched on Baghdad under the leadership of the Būyid family. The Būyids forced the caliph to appoint themselves commanders of all caliphal troops and controlled both Iraq and much of present Iran for the better part of the next hundred years.

Already by the end of the 9th century, the chaos in the centre had led to a loss of caliphal control over many of the more peripheral regions of the Empire. Local governors now did not look to the centre in Iraq anymore, they rather tried to set up independent polities. The East had long been under the sway of the Tāhirids who had kept an eye on developments in Iraq and even had kept their own troops recruited not to a large degree from the social elite of the province. During the gth century the Central Asian regions of the Islamic world that had before been composed of relatively small local principalities paying allegiance to Baghdad came under the rule of the Sāmānid family who managed not only to subdue the whole of the Transoxanian and large parts of the Eastern Iranian world, but also at the end of the gth century had more or less a monopoly for supplying the caliph with the slave soldiers he so desperately needed. The Sāmānids would not only export slave soldiers to the West; they also constituted their own armies of Turkish slaves. When the original base of their military, the rural aristocracy of the region, disaffected because of their declining influence, lost their interest in the continuance of

19 De la Vaissière, Samarcande et Samarra, pp. 267-268.

20 Kennedy, "Military". 
Sāmānid rule around the year 1000, they finally lost power to the descendants of one of their slave generals, the so-called Ghaznavid dynasty. ${ }^{21}$

In the far West, a scion of the Umayyad dynasty had founded an emirate on the Iberian Peninsula. The armies of al-Andalus consisted of different competing networks based on ethnic and tribal bonds. This led to instability that the Umayyads sought to overcome by recruiting slave soldiers imported from Central Europe. Numbering 14,00o they were an important prop of the Andalusi caliphate's power, serving both in the military and in the administration, during the reign of 'Abd al-Rahmān III (ruled 912-961). At his death, some of them made an unsuccessful attempt to seize power. However, this was not the end of their influence, factions of them and other segments within the elite took part in a general scramble for the spoils after the breakdown of central authority in the first decades of the 11th century. ${ }^{22}$

Ibrāhīm ibn Aghlab (80o-812), the founder of the dynasty of semi-independent governors of Ifrīqiyā, seems to have been the first ruler in the Muslim world to set up an army of slaves, long before his overlords at Baghdad and Samarra. He thereby freed himself from dependency of the djund, the Ifriqian militia. A complete army corps made up of 5,000 slaves was settled in a quarter of their own in the Aghlabid capital of al-Abbāsiyya. A few decades later Ahmad ibn Țülūn, the 'Abbasid governor of Egypt, who had himself been a slave, founded his own slave army there to secure his power over Egypt. The existence of slave regiments had by the 1oth century become the rule within the realms of the Muslim world. The Fățimids who pretended to be descendants of the prophet with a better claim to the caliphate than the Abbasids were another example. At the beginning, they founded their military might in the Maghreb on the support of the Kutāma Berbers. Having gained control over Ifrīiya at the beginning of the 1oth century, they recruited troops of slaves. They continued this practice after they had transferred the seat of their caliphate to Egypt in the 96os. In the Fāțimid Empire as elsewhere, in periods of crisis regiments of different origins started fighting against each other in alliance with factions at court. ${ }^{23}$

21 Paul, The State and the Military.

22 Golden, "Șakāliba". For a critique of the view that Central European șaqāliba served as soldiers see Kenaro, "Slave Elites" who claims that the șaqāliba proper served as palace officials and not as soldiers. Those who were called șaqāliba but served as soldiers were of different origin.

23 Lev, "David Ayalon". 
Slave troops, as we have seen, came from where they could easily be provided, that is from neighbouring regions to which the respective ruler had military or commercial access. All peoples around the Muslim world (more or less all peoples anywhere) had groups within their societies that had military traditions. Therefore, it does not make great sense to think about some groups being preferred because they belonged to what European imperialists of the 19th century labelled "martial races". As it was, many recruits came at a rather young age anyway and, apart from the case of the first decades at Samarra, the better part of their military training took place within the Muslim realm(s). Nonetheless, there were certain ethnic prejudices and stereotypes that to some degree were derived from learned traditions (see below), but to some degree might have had a foundation in real conditions. Turks were mostly used as horsemen and it may well be that these Central Asians had indeed normally mastered riding at a very young age before being sold into slavery. Sub-Saharan Africans, by contrast, were normally used as infantry. Again, horses being rare in their country of origin one could not presuppose any anterior experience of horsemanship, while they might have been used to walking long distances.

In the case of the Abbasid caliphs, the greatest number of slave soldiers came from Central Asia. Most of them will have been speakers of Turkish languages, but taking into account the imbricated nature of Central Asian ethnicities, it may well be that some whom we (perhaps even their contemporaries) conceptualize as Turks spoke other Iranian or Altaian languages. These Turks were in part prisoners of war and as such came to the Muslim lands as already fully-fledged soldiers. Such people, as we have seen, often have had a rather high standing in their society of origin. Others had come into the possession of their Muslim masters as young children as war booty or tribute. In these cases, we cannot be as sure concerning the standing of these persons before their enslavement, nor did it probably play a big role. ${ }^{24}$ In the North, war against the Khazars, the great trading Empire around the Caspian Sea, might have provided further human resources. It seems that in times of peace the Khazar elites, for the most part Turkish-speaking and of Jewish religion, were also willing to sell heathen subjects into slavery. ${ }^{25}$ The Khazars were at some distance from the caliphs' seat of power in Iraq. Since the caliphs had lost direct control of most outlying provinces at the end of the gth century, they became dependant on having governors loyal to them in Central Asian frontier regions to

24 All this is intensively discussed in De la Vaissière, Samarcande et Samarra.

25 Golden, "Khazar Turkic Ghulâms". 
provide them with the slaves they needed for their armies. The North East, where the Sāmānids were always willing to help, was the most important source for military manpower left to the caliphs.

The ever more visible prevalence of Turkish troops in Abbasid service was not a question of principle but rather of necessity. During the gth century, the Abbasids had been quite willing to use slave regiments of Africans. The Muslim rulers of Egypt, first the semi-independent governors of the Abbasids, then even more the rival caliphal dynasty of the Fātimids, probably did not have a very strong interest in providing the caliph with fighters. By consequence, after the mid-9th century it will have become increasingly difficult for the caliphs to get African soldiers from the Nile region and countries further to the West. East Africans had been recruited during the 9th century and even later, but, as it seems, this practice slowly petered out after people of that origin had been responsible for the rebellion of the plantation slaves that laid waste Iraq in the late 9th century. ${ }^{26}$ As has been said, Africans served mostly as infantry. Another important group within the caliphal armies had been the already mentioned Maghāriba, i.e. Westerners, Muslim Arabs from Egypt. These could of cause not be easily replaced, as the enslavement of Muslims had become more and more of a taboo. Therefore, at the end of the day the caliphs had no other resources for military slaves than what came to them from the Northeast. This gave the Muslim rulers of that region some advantage over the centre. On the other hand, it meant that after the abna $\bar{a}^{2}$, the shäkiriyy $a^{27}$ and other nonTurkish groups of slave soldiers had disappeared, the idea of putting one group of soldiers against the other became difficult a game for the caliphs.

As had been said, in other regions of the Middle East, for reasons of geography, Turks did not play the same role as for the caliphs and the Sāmānids. This did not mean that slave soldiers were of no importance there; only the countries they stemmed from differed. In Umayyad Spain, it was the regions to the North that provided slave troops that helped the dynasty in the gth century to become more independent from the different segments of Andalusian society. These slave soldiers, some of them Eunuchs, were commonly called Saqāliba, Slavs. If all of them were indeed of Central European origin remains a moot point. Sources sometimes speak a bit confusingly about them and other peoples, both from the Iberian Peninsula and from Carolingian Europe. As it seems, though, the majority of these troops were imported by slave traders who had acquired them from the (Eastern) Franks who during the times were leading wars against the Slav populations in the Elbe region. As is well known,

26 Bacharach, "African Military Slaves".

27 On these De la Vaissière, Samarcande et Samarra and Kennedy, Armies of the Caliphs. 
Verdun in France was a leading centre of this trade (and the castration of future eunuchs). Another major place where Eunuchs were castrated and traded was Lucena in Spain. Many of the traders were Jews who had the contacts and the language skills to successfully perform this kind of transcultural transactions. ${ }^{28}$

The first dynasty to seek the support of slave troops had been the Aghlabid governors of North Africa. Ifrīiyā was home to a large population of subSaharan slaves working in the region's agriculture. ${ }^{29}$ As there were intensive trading contacts across the Sahara to provide the region with ever-new generations of slaves it was no far-fetched idea to use these contacts to create a slave militia. Slave trading across the Sahara was in the hands of Berber groups who ironically had themselves fallen prey to Muslim slave raiding in the first century of Islam. Some of these Berber groups had rebelled against their treatment by their Arab masters and established independent polities in what is now Algeria. ${ }^{30}$

Sub-Saharan Africa was not the only source of military slaves for the Aghlabids. Raiding and more regular warfare on sea also provided them with slaves from the northern shores of the Mediterranean who could be put to military use. Another source were Italian traders who delivered Central and Eastern Europeans. ${ }^{31}$

The Fātimid successors of the Aghlabids in North Africa had first build their power on the support of free groups of Kutāma Berbers. Rather soon, they took over the military recruitment policies of their predecessors. Both before and after the transfer of their capital city to Egypt they counted to a large degree on African slave troops. In Egypt they found a local tradition of African slave soldiers going back to the semi-independent Abbasid governor Aḥmad ibn Ṭūūn, but these Africans were probably of Nilotic rather than West African origin. Apart from these, called sūdān, blacks, there were also black slave troops from East Africa, called zandj. Besides, the Fāțimids also had șaqāliba in their service. By contrast to the șaqa)liba in al-Andalus these came, as it seems, rather from Eastern Europe by way of the Crimea or by way of Italy. From the mid-gth century onwards, officers of Slavonic origin played a leading role in the Fāțimid

28 Golden, "Șakāliba”; Verlinden, "Les Radaniya”. The role of European Jews has lately been questioned in Toch, "Jews and Commerce".

29 Lev, "David Ayalon".

30 Berger, Entstehung des Islam, pp. 216-217. There is in fact an abundance of information available on how trade was transacted south of the Sahara and what groups of peoples were sold as slaves or who served as middlemen providing the Berber traders with what they wanted. See e.g. relevant chapters in Lane/MacDonald, Slavery in Africa. 
state. Djawhar, the military commander that conquered Egypt for them, e.g. was of Slavonic extraction. ${ }^{32}$ There were also Turkish and Persian soldiers who presumably were not slave troops but free. They were trying to wrest power from the hands of the Africans during the difficult period of al-Muntasiir's reign (1036-1094). The African slave infantry remained the mainstay of Fāțimid power. It was these troops that Saladin had to fight against in his effort to gain control of Egypt in the 116os. After their defeat, African slave troops never again played a similar role in Egyptian affairs. ${ }^{33}$ The future belonged to slave soldiers of Turkish and Circassian extraction.

As it seems, most Turkish or Central Asian slave soldiers in Iraq, at least in the 9th century, insofar as they had been slaves at all, were liberated at some point rather early in their career. They were called mawālī, clients, not slaves anymore. Others, it seems, kept their slave status. However, in a way the legal status of a person was not always the most important factor determining the social position of a person in medieval Muslim societies. Slave soldiers became part of the institutions of government and their social position was a result of their proximity to the seats of power. The influence and standing of the caliphs' slave soldiers was not liked by large parts of the population in the capitals of medieval Muslim polities. This had something to do with the foreignness of these troops. While some of their leaders became perfectly conversant in the intricacies of Muslim-Arab culture, the majority of the rank and file certainly remained strangers to most of the language and world of the societies they were supposed to protect. By consequence, envy of the slave armies' position could easily be expressed in ethnic terms. It is no wonder that foreign soldiers who lorded it over the general population and more and more even the caliph himself were disparaged for their lack of Arabness. They were kept purposely in isolation from the locals.

Racial stereotypes and prejudices were readily available for people of any origin. The Turks were held to be warlike and honest but at the same time seen as primitive and violent. The cold climate of their country of origin was thought

32 Golden, "Șakāāiba".

33 Lev, "David Ayalon"; Bacharach, "African Military Slaves".

34 On race-thinking still Lewis, Race and Slavery and the literature given in Berger, Gesellschaft und Individuum, pp. 146-147. 
to have made them fat and sexually rather disinterested..$^{35}$ They were at times compared to riding apes. Racialist images in the medieval Muslim world came partly from classical tradition, ${ }^{36}$ partly they were created ad hoc in the Islamic world as when Slavonic peoples were held to be similar to dogs. This idea was obviously inspired by their Arabic name, șaqāliba, that came from Persian sag, dog. ${ }^{37}$

Racial slurs were current not only at the expense of the Turks, but also of sub-Saharan Africans. African slave soldiers were distinguished from others by being called 'abid, a particularly negative word for slaves. ${ }^{38}$ On account of a presupposed racial inferiority, even highest-ranking people of African origins could be subject to slander. One of the most famous instances of this were the verses the great poet al-Mutanabbī wrote at the expense of Kāfür, the castrated former slave who had risen to become ruler of Egypt in the 1oth century. ${ }^{39} \mathrm{On}$ the other hand, supposed ethnic features could be a matter of praise, as in the 9th-century author al-Djāhiz' essays on the virtues of both the Turks and the Africans. Both ways, ethnicity was an important way of constituting social order and conceptualising conflicts. This held true not only for the original inhabitants of the Middle East, but also among the slave troops themselves. They were, as we have seen, grouped following ethnic lines and often fought out conflicts among themselves accordingly.

However, all this does not mean that race-thinking as such was a major cause of strife in the societies in question. Of course, Turkish regiments of cavalry would fight against black infantry soldiers to defend their interests. Of course, once you had fallen out with an important person, you would mock him on account of his origins as al-Mutanabbī did with Kāfür. Nevertheless, neither the Turkish regiments nor al-Mutanabbī had a conflict with their respective counterparts just because they were black. Conflict was not caused by ethnical or racial prejudice. Rather, once there was conflict, people would stick to whosoever was part of their group. Regiments being formed along ethnic lines; it was self-evident that people of the same origin had common interests. At the same time, it was only logical that in this situation people would use racial stereotypes as well as anything else at hand to have the better of their respective enemies. Political correctness certainly was no feature of pre-modern Muslim society.

35 Bosworth, "Turks".

36 On the foregoing and the Arab literary tradition on Turks from Abbasid times to the Ottoman period more generally Berger, Gesellschaft und Individuum, pp. 146-147.

37 Golden, "Ṣakāliba".

38 Golden, "Ṣaḳāliba".

39 Lewis, Race and Slavery, pp. 59-6o. See also Bacharach, "African Military Slaves". 

Institution

Slave soldiers existed in many civilisations from Antiquity until the petering out of slavery at the end of the 19th century. ${ }^{40}$ This is not surprising. Slaves were a weak social group and in many societies being a soldier was not a station of high prestige. Furthermore, not all societies bind military service and citizenship together in the way the classical Greece and Rome, the early Islam, and the European 19th century did. In our own days, the abolition of conscription made the army again a place for marginalized social groups. The same had already held true in the late Roman Empire where the armies were formed more and more by people who had only lately entered the Roman world. Slavery in modern society is regularly conceptualized along the lines of American race-based plantation slavery. This makes the idea of arming a totally subdued, even dehumanized group seem a strange idea (although even West Indian slaves could be armed at times) ${ }^{41}$. If we see slavery not in these stark terms but simply as one form of marginal or subordinate position that people could have in society, we might put the question differently: Under which conditions did the leading social groups of medieval societies stop doing military service and were replaced by people from the margins, both socially and geographically? Military slavery then is only a particular case of recruitment of marginal people.

Ayalon put forward that a lack of manpower was the root cause of the employment of slave soldiers. ${ }^{42}$ Pipes in a way followed the same path. With conversion of large sectors of the population in Iran, the Muslims did not feel threatened anymore, djihād had ceased to be successful and revolutions had brought disillusioning results. By consequence, Muslims were less and less interested to participate in public affairs after the beginning of the gth century. ${ }^{43}$

Crone also argued that Muslim rulers lacked legitimacy in the eyes of the elite of their Muslim subjects. The Abbasids had tried to found their rule on an alliance with the elites of Khorasan, who happened to have a strong military tradition. Once this alliance was broken in the crisis of the civil war at the

$40 \quad$ Crone, "Early Islamic World".

41 Pipes, Slave Soldiers, pp. 39-40.

42 Ayalon, "Military Reforms".

43 Pipes, Slave Soldiers, pp. 181-182. 
beginning of the gth century, they had to look elsewhere. To create a militia with personal ties to the caliph seemed the only solution. ${ }^{44}$

Rulers of the Islamic world of the 1oth century could never be sure that their legitimacy was not called into question. Hence, the idea to have troops with special loyalty to their persons must have been attractive. What is more, units of different origins and of differing dates of recruitment could be put one against the other so as to create a complicated web with the ruler as the final arbiter in all conflicts between factions. Creating a slave army as did the Aghlabids by inventing the Muslim slave militia at the beginning of the gth century gave rulers a new and important means of keeping the upper hand in the difficult game of army and court politics.

In the Abbasid case, another point seems to have been of importance. While at the beginning of the conquests infantry played a decisive role in warfare, by the 9 th/1oth century the importance of cavalry was increasing. ${ }^{45}$ Who could be called to serve in a mounted militia? Only rich landowners could afford to pay for their mount and serve and had learned how to use a horse right from childhood. In medieval Western Europe, the increasing importance of cavalry led to the formation of feudal society where in the end only mounted soldierlandowners were really free. In the Muslim world, things were different. The conquests had settled the new Arab-Muslim masters in cities. They did not live on their own landed property but on stipends payed by the government. After a few decades, they had become less than enthusiastic soldiers. War was not as profitable as during the first years of the conquests and life in the metropolises of the Muslim world was more amenable than campaigning in foreign parts. Service to religion for many did not consist in armed engagement anymore but in scholarship. The complicated business of learning how to fight effectively on horseback was not part of the cultural heritage of these Muslim communities. This was different in Eastern Iran and Central Asia. Here there still existed significant numbers of a Muslim (convert or otherwise) landed aristocracy who had the means to serve as cavalry and for whom this was an important part of their cultural tradition. As we have seen in the beginning, the caliphs tried to attach to themselves noble groups of this origin and it was only when they proved unreliable that they took to importing them as slaves. Coincidentally, in the East as well the Sāmānids at first relied on their landed aristocracy for having a mounted army. Such a takeover did not happen quickly. Normally, fidelity was one of the assets of creating the quasi-familiar bond of slave soldier and master. The master's position was further strengthened if he had the possibility

44 Crone, "Early Islamic World".

45 Kennedy, Armies of the Caliphs, pp. 172-173. 
to shower his favours on other clients and networks as well. However, loyalty could also be produced by other means: in particular, the troops' belief in the religious legitimacy of the ruler. The continued existence of the Abbasid caliphate after 945 had much to do with this fact. However, this legitimacy was rather effaced and could not be turned into massive coercive power. Things were different with the kind of intensive religious charisma that helped the Fātimids to gain the military support of the Kutāma Berbers. ${ }^{46}$ Only when this charisma faded did the dynasty come to rely more heavily on what by now had become the traditional system of slave troops. Last but not least, group solidarity of geographically marginal, often nomadic groups, the medieval sociologist Ibn Khaldūn's famous 'așabiyya, remained a central source of military power. A great number of Muslim Empires during the course of the Middle Ages relied on just that. ${ }^{47}$

This being so, it is an error to assume that slave armies had become the only source of military power in the Muslim Middle East after the 1oth century. The Mamluk Empire in Egypt remained exceptional. Rulers had a whole range of resources on which to base their power. Nonetheless, those instruments of power, different from what was the rule in the Western Early and High Middle Ages, nearly never stemmed from the elites of their society. Neither slaves nor nomadic tribes had a high standing as long as they had not become the instrument of the ruler's might. Those with high standing, scholars and traders, could make their voice heard by literature and religion, but they had lost any coercive force.

\section{Bibliography}

Amitai, R., "The Rise and Fall of the Mamluk Institution: A Summary of David Avalon's Works", in M. Sharon (ed.), Studies in Islamic History and Civilization in Honour of Professor David Avalon, Jerusalem 1986, pp. 19-30.

Ayalon, D., "The Military Reforms of Caliph al-Mu'tasim", in D. Ayalon (ed.), Islam and the Abode of War: Military Slaves and Islamic Adversaries, Aldershot 1994, pp. 1-39. Ayalon, D., "Preliminary Remarks on the Mamluk Military Institution in Islam", in V. Parry (ed.), War, Technology, and Society in the Middle East, London 1975, pp. 44-58.

46 These, in their way, had been nearly as marginal to Ifrìqian society up to that point as African slaves.

47 The role of marginal groups for empire building has been stressed by Martinez-Gros, Brève histoire. 
Bacharach, J., "African Military Slaves in the Medieval Middle East: The Cases of Iraq (869-955) and Egypt (868-1171)", International Journal of Middle East Studies 13 (1981), pp. 471-495.

Berger, L., Die Entstehung des Islam: Die ersten hundert Jahre, München 2016.

Berger, L., Gesellschaft und Individuum in Damaskus, Würzburg 2007.

Bonner, M., "The Waning of Empire, 861-945", in: C.F. Robinson (ed.), The New Cambridge History of Islam. Vol. 1: The Formation of the Islamic World, Sixth to Eleventh Centuries, Cambridge 2011, pp. 305-359.

Bosworth, C.E., "The Turks in the Islamic Lands up to the Mid-nth Century", in C. Cahen (ed.), Philologiae Turcicae fundamenta, Wiesbaden 1970, pp.1-20.

Cahen, C., "L'évolution de l'iqtâ du IXe au Xıııe siècle: contribution à une histoire comparée des sociétés médiévales", Annales. Économies, Sociétés, Civilisations 8 (1953), pp. $25^{-52}$.

Cobb, P., "The Empire in Syria, 705-763", in: C.F. Robinson (ed.), The New Cambridge History of Islam. Vol. 1: The Formation of the Islamic World, Sixth to Eleventh Centuries, Cambridge 2011, pp. 226-268.

Crone, P., "The Early Islamic World", in K. Raaflaub (ed.), War and Society in the Ancient and Medieval Worlds, Cambridge 1999, pp. 309-332.

Crone, P., Slaves on Horses: The Evolution of the Islamic Polity, Cambridge 1980.

De la Vaissière, É., Samarcande et Samarra. Élites d'Asie centrale dans l'Empie Abbaside, Paris 2007 .

El-Hibri, T., "The Empire in Iraq, 763-861", in: C.F. Robinson (ed.), The New Cambridge History of Islam. Vol. 1: The Formation of the Islamic World, Sixth to Eleventh Centuries, Cambridge 2011, pp. 269-304.

Golden, P., "Khazar Turkic Ghulâms in Caliphal Service”, Journal Asiatique 292 (2004), pp. 279-309.

Golden, P., Art. “al-Șaḳāliba”, Encyclopeadia of Islam, Second Edition, vol. 8, Leiden 1995, pp. 872-881.

Gordon, M., "The Turkish Military Elite of Samarra and the Third Century Land Tenure System", in M. Toru (ed.), Slave Elites in the Middle East and Africa, London 2000, pp. $13^{-24}$.

Kenaro, S., "Slave Elites and the Saqāliba in al-Andalus in the Umayyad Period", in M. Toru (ed.), Slave Elites in the Middle East and Africa: A Comparative Study, London 2000, pp. 25-40.

Kennedy, H., "The Military", in M. van Berkel et al. (ed.), Crisis and Continuity at the Abbasid Court, Leiden 2013, pp. 111-141.

Kennedy, H., "The Decline and Fall of the First Muslim Empire", Der Islam 81 (2004), pp. 3-30.

Kennedy, H., The Armies of the Caliphs: Military and Society in the Early Islamic State, London 2001. 
Lambton, A., Art. "Eqtā", Encyclopcedia Iranica, vol. 8, New York 1998, pp. 520-533.

Lane, P./MacDonald, K.C., Slavery in Africa: archaeology and memory, Oxford 2011.

Lev, Y., "David Ayalon (1914-1998) and the History of Black Military Slavery in Medieval Islam", Der Islam 90 (2013), pp. 21-43.

Lewis, B., Race and Slavery in the Middle East, Oxford 1990.

Martinez-Gros, G., Brève histoire des empires, Paris 2014.

Paul, J., The State and the Military: The Samanid Case, (Papers on Inner Asia, 26), Bloomington IN 1994.

Pipes, D., Slave Soldiers and Islam: The Genesis of a Military System, New Haven 1981.

Shaban, M., Islamic History: A New Interpretation, Cambridge 1976.

Sourdel, D., L'État impérial des califes abbasides, Paris 1999.

Talbi, M., Art. "Maghāriba", Encyclopaedia of Islam, Second Edition, vol. 5, Leiden 1986, pp. 1159-161.

Toch, M., "Jews and Commerce: Modern Fancies and Medieval Realities", in: S. Cavaciocchi (ed.), Atti della XXXI settimana di studi, Istituto Francesco Datini, Prato. Il ruolo economico delle minoranze in Europa, Secc. XIII-XVIII, Florence 2000, pp. $43^{-58}$.

Töllner, H., Die türkischen Garden am Kalifenhof von Samarra. Ihre Entstehung und Machtergreifung bis zum Kalifat al-Mu'tadids, Bonn 1971.

Verlinden, C., "Les Radaniya et Verdun: à propos de la traité des esclaves slaves vers l'Espagne musulmane aux Ixe et xe siècles", in: M. del Carmen Carlé (ed.), Estudios en homenaje a Don Claudio Sánchez Albornoz en sus go años, vol. 2, Buenos Aires 1983, pp. 105-132. 